


\title{
Establishment of the institution of covert investigation in the criminal justice system of Ukraine
}

\author{
DOI: https://doi.org/10.46398/cuestpol.3969.29
}

Oleh Tarasenko *

Maksym Tsutskiridze **

Artem Shevchishen ***

Yuri Yermakov ****

Dmytro Mirkovets $* * * * *$

\begin{abstract}
The purpose of the article is to study the formation of the covert investigation institution in the criminal justice system of Ukraine. The subject of research is the prerequisites for the establishment of this institution in Ukraine. Research methods are chosen considering the stated purpose and tasks, object, and topic of the study. Consequently, the article uses general and specific scientific methods. Among the results of the research, the realization of an analysis of the international experience of operation of similar institutions in developed countries stands out. Problematic issues of the formation of the covert investigation institution in Ukraine are identified. In conclusion, it is noted that Ukraine has opted for a covert investigation system, the mechanism of which is more geared towards solving crimes - "incidents", when it is not necessary to hide the fact of the investigation. In terms of the practical implications, the peculiarities of the operation of the covert investigation institution in the criminal justice system of Ukraine are highlighted and, based on the investigation carried out, the definition of the perpetrators of the mentioned legal category is offered.
\end{abstract}

* Candidate of Legal Sciences, Associate Professor, Associate Professor Department of the Department of operational and search activities of the National Academy of Internal Affairs, Ukraine. ORCID ID: https://orcid.org/oooo-0002-3179-0143. Email: ko12@naiau.kiev.ua

** Doctor of Legal sciences, Associate Professor, Professor of the Department of Criminal Procedure of the National Academy of Internal Affairs, Ukraine. ORCID ID: https://orcid.org/oooo-0002-5880-8542. Email: koo7@naiau.kiev.ua

*** Doctor of Legal sciences, Associate Professor, Professor of the Department of Criminal Procedure of the National Academy of Internal Affairs, Ukraine. ORCID ID: https://orcid.org/oooo-0002-1342-6639. Email: Krum.proces@ukr.net

${ }^{* * * *}$ Candidate of Legal Sciences, Associate Professor. ORCID ID: https://orcid.org/oooo-0002-94000604. Email: YermakovYu@ukr.net

***** Candidate of Legal Sciences, Associate Professor, Associate Professor of the Department of Public Law Disciplines of Private Higher Education Institution «University of Modern Knowledge». ORCID ID: https://orcid.org/oooo-0oo3-2539-2824. Email: sekretariat@umk.edu.ua 
Keywords: concept formation; criminal justice system; undercover investigation; covert investigation (trespassing); criminal justice in Ukraine.

\section{Establecimiento de la institución de investigación encubierta en el sistema de justicia penal de Ucrania}

\section{Resumen}

El propósito del artículo es estudiar la formación de la institución de investigación encubierta en el sistema de justicia penal de Ucrania. El tema de la investigación son los requisitos previos para el establecimiento de esta institución en Ucrania. Los métodos de investigación se eligen teniendo en cuenta el propósito y las tareas declaradas, el objeto y el tema del estudio. En consecuencia, el artículo utiliza métodos científicos generales y específicos. Entre los resultados de la investigación destaca la realización de un análisis de la experiencia internacional de funcionamiento de instituciones similares en los países desarrollados. Se identifican cuestiones problemáticas de la formación de la institución de investigación encubierta en Ucrania. Como conclusión se observa que Ucrania ha optado por un sistema de investigación encubierta, cuyo mecanismo está más orientado a resolver los crímenes - "incidentes", cuando no es necesario ocultar el hecho de la investigación. En términos de las implicaciones prácticas se destacan las peculiaridades del funcionamiento de la institución de investigación encubierta en el sistema de justicia penal de Ucrania y, sobre la base de la investigación realizada, se ofrece la definición de los autores de la categoría legal mencionada.

Palabras clave: formación de conceptos; sistema de justicia penal; investigación encubierta; acciones de investigación encubierta (allanamiento); justiciar penal en Ucrania.

\section{Introduction}

Crime is characterized by rapid adaptation to the protective mechanisms of the State. Therefore, the effectiveness of detection and investigation of criminal offenses is possible only in the case of the use of adequate means of obtaining evidence, which leads to the use of appropriate tools, the use of covert measures, means and methods of law enforcement. Until 2012 the existing system of criminal justice was largely based on a significant (in some cases) restriction of the rights and freedoms of citizens; the State, not 
Oleh Tarasenko, Maksym Tsutskiridze, Artem Shevchishen, Yuri Yermakov y Dmytro Mirkovets Establishment of the institution of covert investigation in the criminal justice system of Ukraine

having adequate threats of levers of influence, tried to solve the problem of combating crime by not procedural measures (including search operations). But the development of interstate relations, internationalization of crime, and extraterritorial nature of criminal groups forced law enforcement agencies of different countries to search for the most effective mechanisms of cooperation in law enforcement, which necessitated the unification of relevant legislation (Denysenko, 2017). Democratic transformations, the State's course towards European integration have forced to reconsider the doctrinal approach and change the criminal procedure legislation, and the legislation regulating operational and investigative activities. The reform of the criminal justice system in Ukraine and the adoption of the Criminal Procedure Code of Ukraine have established a number of new institutions in the domestic criminal procedure legislation. Modern criminal procedure legislation has undergone significant changes, in particular to ensure the rights of participants in criminal proceedings, the introduction of adversarial proceedings, improving the collection of evidence, increasing guarantees of privacy, expanding judicial control over restrictions on constitutional human rights and freedoms at the stage of pre-trial investigation (Cherniavskyi et al., 2013). There has been a transformation of the institutions of criminal justice - operational and investigative activities and pre-trial investigation, the functional association of which has been consolidated in criminal proceedings as an institution of covert investigations. Nowadays, the current criminal procedure legislation of Ukraine is largely integrated into the European legal space of regulation of criminal procedural legal relations. The introduction of covert investigative (search) actions in the legal area testifies to the evolution of current criminal procedure legislation, the existence of democratic changes in the criminal justice system of Ukraine, but the formation and development of covert investigations remains one of the most controversial issues of the criminal justice system.

So, the purpose of the article is to determine the peculiarities of the formation and concept of the institution of covert investigations in the system of criminal justice of Ukraine.

\section{Methodology}

Research methods are chosen taking into account the stated purpose and tasks, object and subject matter of the study. Dialectical method as a general method of scientific cognition helps to consider all the issues in the dynamics, reveal their relationship and interdependence, examine the state of scientific development of the institution of covert investigation in the system of criminal justice of Ukraine. Historical and legal method is applied to study establishment of the institution of covert investigation in 
the criminal justice system of Ukraine. System analyses method, as well as formal and logical method make it possible to analyze the legal support for the institution of covert investigation in our State. Formal and legal method allows to reveal the powers of the actors of this activity (prosecutor, investigator and detective). System and structural method is helpful in identifying the types of criminal justice systems of different countries. Comparative and legal method is used to compare the procedures for the application of covert measures within criminal justice systems of some States of the world.

\section{Literature Review}

The adoption of the Criminal Procedure Code of Ukraine (Law No. 4651-VI, 2010) has provoked some discussions on the introduction of the mechanisms of operational and investigative activities (regarding the receipt of evidentiary information in a tacit manner) in the criminal process. Therefore, the study of the institution of covert investigations has attracted the attention of a number of scholars, who devoted both monographic studies and individual scientific publications to this issue. In particular, Hahach (2017) determined the functions of procedural guidance in the process of covert investigations. Omelianenko (2015) singled out the aspects of the interaction between the investigators and authorized operational units in the course of covert investigations. Pohoretskyi (2012) investigated the introduction of the institute of covert investigations in law enforcement practice. Salo (2018) considered the peculiarities of the powers of the head of the pre-trial investigation agency when conducting covert investigative (search) actions. Serhieieva (2014) defined the principles of using materials obtained in the course of covert investigation in criminal proceedings. Shcherbakovskyi, Stepaniuk, Kikinchuk, Oderiy and Svyrydova (2020) studied the significance of such measures in combating corruption offences and came to the conclusion that quite often information that records the circumstances of corruption acts can only be collected by interfering with private communication, using confidential cooperation, and other covert investigative actions. Tahiiev (2015) defined the mechanism of realization of the institution of covert investigations in the criminal process of Ukraine. Tatarov (2016) highlighted the number of problems that may occur when performing covert investigative (search) actions.

Different aspects of covert investigation were also examined by a number of foreign scientists. For example, Shabde and Craft (1999) studied the problem of covert video surveillance in cases of suspected child abuse and came to the conclusion that it is justified when if it is necessary to protect the interests of a child and if the child is at serious risk of abuse. However, this measure can be applied only using local child protection procedures, which will include medical, nursing, social work, and police staff. 
Harfield (2010) stressed that the wide use of covert actions necessitates the dialogue about their direction and governance. That is due to the fact that nowadays it is not the only effective means to prevent crime, as the data obtained with its help cannot be proved by witness testimony at trial.

Loftus and Goold (2012) investigated covert surveillance conducted by the police and try to highlight some peculiarities of this activity. In particular, the authors demonstrated how exactly police officers manage to be invisible in order to infiltrate into suspect's daily routine.

Loftus (2019) proved that today covert surveillance is a normal activity in Britain, which is legally regulated and having a lot of tools in its arsenal. As policing has become public business lately, covert measures are increasingly important.

Thus, having studied various aspects of the use of the institution of covert investigations, we can state that most of the scientific developments are related to the implementation of its sample provisions; many of them contain controversial provisions; some views are insufficiently substantiated. As a result, a conceptual model for the implementation of the institution of covert investigations in the criminal justice system of Ukraine has not yet been developed.

\section{Results and Discussion}

The introduction of the institution of covert investigations into the criminal process was preceded by the analysis of foreign experience in relation to the similar institutions envisaged by criminal procedure legislation of foreign countries. Thus, such procedure was due to the fact that enshrining the possibility of inspection and seizure of correspondence, control of telephone conversations in certain rules of the Criminal Procedural Code of Ukraine of 1960 (Law No. 1001-05, 1960) was insufficient to rehabilitate Soviet methods of obtaining information by using covert measures and use them in evidence (Salo, 2018). Operational and investigative activities, which were carried out mainly before the pre-trial investigation, did not fully allow the application of due process, as they were based on departmental regulations, and in most cases their results were not considered a procedural source of evidence. The gradual democratization of society required the changes in the criminal justice system. The Criminal Procedural Code of Ukraine of 1960 (Law No. 100105, 1960) has already provided for the use of operational and investigative activities in the interests of criminal justice by imposing the obligation on the criminal inquiry to take necessary operational and investigative measures in order to identify the signs of a crime and their perpetrators (Part 1, Article 103). Although the said Criminal Procedural Code (Law 
No. 1001-05, 1960) did not directly indicated the possibility of using the materials of operational and investigative activities as reasons and grounds for initiating a criminal case, conducting certain investigative actions and making other procedural decisions, as well as for obtaining factual data that may be evidence in a criminal case, the content of a number of its norms (Articles 65, 66, 78, 83, 94, 103, 104, 106, 177, 178, etc.) provided for such a possibility (Serhieieva 2014, p.153). Later, the Law of Ukraine of June 21, 2001 (Law 2670-III, 2001) amended and supplemented Art. 187, 187-1 of the Criminal Procedural Code of Ukraine of 1960 (Law No. 1001-05, 1960); the list of investigative actions was expanded by withdrawal of information from communication channels, seizure of correspondence, which created the legal basis for the application of this covert method for obtaining information about a crime in criminal proceedings. Part 2, Art. 65 of the CPC of Ukraine was supplemented by the provision stating that the actual data constituting the content of the evidence is established, including protocols with relevant annexes, drawn up by the authorized bodies as a result of operational and investigative activities.

However, this did not change the basic approach to the fact that covert measures were carried out exclusively by operational within operational and investigative activities; covert pre-trial investigation was aimed primarily at ensuring the interests of the State and created a duplication, which the Council of Europe experts considered to be as "a cumbersome, with numerous replications, a three-stage criminal process of the Soviet type" in the conclusion of November 2, 2011 (Council of Europe, 2011). Besides, the institution of operational and investigative activities required a certain reformation, transition from Soviet, secret methods of obtaining information about the crime, as the established procedure for obtaining information about illegal activities of individuals was increasingly recognized by the court as inadmissible evidence (Salo, 2018).

The historical retrospective of the development of Ukrainian society required finding a compromise between the need to effectively combat crime and the principle of justice, ensuring the realization of constitutional rights and freedoms of an individual and citizen, saving forces, means, funds, etc. In fact, Ukraine faces a dilemma - on the one hand, totalitarianism is capable to overcome the criminalization of society, but its consequences can be compared with the consequences of crime for most people; on the other hand democratic society is more focused on individual rights and freedoms, but it does not help to reduce crime rate. Thus, the question of introduction and consolidation of «secret activities» directly into the criminal process, which would make it possible to obtain evidence in a procedural (albeit tacit) way and use the information obtained in evidence, has come up to the legislators. At the same time, the introduction of the institution of covert investigations provided that it was the pre-trial investigation body that would obtain evidence at the stage of pre-trial investigation by both overt and covert methods and techniques (Salo, 2018). 
The institution of covert investigations is widely used in a number of foreign countries, where the functions of operational and investigative activities and pre-trial investigation are performed by the same official (police officer, agent, detective, etc.), who directly uses both public and covert means of crime (Serhieieva 2014, p. 214), except for those that require special knowledge and skills, and which, in this regard, are conducted by special entities. The result is the right of the investigator (detective) as a subject of pre-trial investigation to receive, verify, and use the evidence by public and covert actions.

The criminal procedure legislation of developed countries has in its arsenal the means of covert investigations, the legal justification of the use of which allows to fully ensure the observance of human and civil rights and freedoms. At the same time, the formation of the institution of covert investigations is significantly influenced by the criminal justice system.

For example, covert measures in the United States are recognized as legal methods of investigation, which is called proactive investigation. According to the proactive investigation, all means of obtaining procedurally relevant information are endowed with equal legal force, and their results acquire the status of full-fledged arguments in court, although the right to recognize the latter as judicial evidence remains with the court. That is, operational and investigative information in American justice does not pass through the filter of pre-trial investigation, but comes directly to court, where the question of its admissibility is resolved (including the results of special police operations and secret investigations conducted by prosecutors (Nechai, 2018).

Another system is operating in the countries where covert investigations are conducted exclusively within criminal proceedings and the grounds for conducting them are defined directly in the Criminal Procedural Codes. Analyzing the practice of their application, it can be noted that in this case the criminal justice system is aimed at solving crimes (incidents), when it is not necessary to conceal the fact that an investigation has been conducted (but only to hide interest in a particular person).

The third system is functioning in the countries, where the legislator does not draw a clear line between the actual search and investigative action; for example, the design of the legal provision (Par. 100a "wiretapping" to the Criminal Procedural Code of Germany) allows for covert investigations both in the investigation of a particular criminal case and beyond these limits. Formally, this is not a fact established during the trial, but only the possibility of such a fact - the German legislator intentionally gave the enforcer some room for manoeuvre (to obtain operationally relevant information, which may be transformed into evidence, but at the time it was received there was none (Nechai, 2018). 
Sadly, Ukraine has chosen the second system, although the simplification of the procedural form of investigative actions by transferring evidentiary and relevant consequences to the trial stage, ensuring the process of proving effective guarantees of admissibility of evidence and effective judicial control could have been achieved by legal regulation of admissibility of evidence obtained in the course of performing operational and investigative activities prior to the commencement of pre-trial investigation. The path to the implementation of such a mechanism was indicated by a specialist in the theory of evidence, Professor Mikhieienko (1984), who proposed to separate the notions of proof (factual) and their "procedural sources». Further development of this idea in modern socio-legal realities might lead to the conclusion that it is necessary to use the materials of operational and investigative activities in proving.

But the situation was different and the country's course on European integration forced to choose a different path. The change in the criminal justice system modified the process of gathering evidence in the pre-trial investigation, in particular by granting the prosecution the right to obtain evidence by conducting covert investigative (search) actions, which are regulated by the Chapter 21 of the Criminal Procedural Code of Ukraine (Law No. 4651-VI, 2010) and by Interdepartmental Instruction "On the organization of covertinvestigative(search)actions and the use of their results in criminal proceedings" (ORDER No. 114/1042/516/1199/936/1687/5, 2012). The modern concept of criminal justice is aimed at substantiating and ensuring the effective functioning of the new institution of the domestic criminal process - covert investigations. Although it seems that the basis for the institution of covert investigations is the interpenetration of operational and investigative and criminal procedural activities, but that's not exactly true. Serhieieva (2014) states that covert investigative (search) actions are operational and investigative measures in their essence, but only those that are carried out after the registration of information about the crime in the Unified Register of Pre-trial Investigations.

Tahiiev (2015) believes that the legislator enshrined in the Criminal Procedural Code of Ukraine (Law No. 4651-VI, 2010) the implementation of covert investigative (search) actions by the prosecutor, investigator and detective, and transformed operational and investigative activities performed by operational units into covert investigative (search) actions. In our opinion, this is not entirely in line with the amendments to the Law of Ukraine "On operational and investigative activities" did not lead to the so-called "proceduralization" of operational and investigative measures, namely to limitation of the use of operational and investigative activities in criminal proceedings, but to maintaining the possibility of the use of investigative activities pending the commencement of criminal proceedings. We can agree with the opinion of scientists who believe that the covert activities by the investigator does not mean the regulation of 
procedural activities by operational and investigative rules; on the contrary, technical, and legal techniques, legal categories that were previously used just in operational and investigative activities, acquire certain special, distinctive features, which allows them to be used in criminal proceedings by investigators (Spilnyk and Komarnytska, 2015).

However, in our opinion, the approach to the regulation of covert investigations by analogy with the overt measures of pre-trial investigation causes a number of problems of the basic nature. For example, the Criminal Procedural Code of Ukraine (Law No. 4651-VI, 2010) does not regulate the procedure of using the results of covert investigations. Part 1, Art. 256 of this act states that protocols for covert investigative (search) actions, audio or video recordings, photographs, other results obtained through the use of technical means, seized things and documents or their copies may be used in evidence on the same grounds as the results of other investigative (search) actions during pre-trial investigation.

However, the covert nature of these actions, the need to keep the actors of their conduct in secret, the very fact of their conduct, lack of possibility to prepare protocols under the general procedure (for example, the issue of involving witnesses who should certify the protocol) is the evidence of the impossibility of transposing the rules on the conduct of overt investigative (search) actions to the procedure for conducting covert investigations. Some procedures of covert investigations, in particular the use of materials of covert investigative (search) actions, their declassification are enshrined in by-laws, which ignore a number of important issues such as the access of defense counsel to the materials of covert investigative (search) actions, providing magnetic media (which contains evidence obtained as a result of their conduct) for independent examination, etc. That is, on the one hand, the use of the results of covert investigations in criminal proceedings differs from the similar application of the results of operational and investigative activities by a simplified mechanism that eliminates the need for additional legalization and promotes the speed of use of documents, but on the other hand, the lack of clear regulation of these procedures directly in the Criminal Procedural Code of Ukraine (Law No. 4651-VI, 2010) significantly reduces the effectiveness of covert investigations. Another problematic issue is the regulation of document circulation in the case of the involvement of specialized operational units in the implementation of covert investigations (including the conduct of individual operational and investigative activities), the tactics of which, as well as the identities of the officers and confidants should remain secret.

In our opinion, it is necessary to clearly define the criteria for distinguishing the concept of the institution of covert investigations from the institution of pre-trial investigation and their relationship. 
The term "covert investigation" is used in a number of countries for the measures to obtain "covert" information. This term provides for "hidden", "covert", "secret" criminal proceedings within the investigation of crimes by authorized bodies on the basis of a reasoned decision, and the results will be used in proof as well as overt (transparent) ones (Salo, 2018).

\section{Conclusion}

The institution of covert investigations in the criminal justice system of Ukraine has certain features that distinguish it from the similar institutions in other countries, namely:

- authorization of the investigator with equal possibility of conducting both investigative (search) actions and covert investigative (search) actions;

- determination of the legal status of operational units in criminal proceedings;

- unification of the actors of covert investigations, including the introduction of the institution of detectives instead of investigative and operational units;

- multi-subjectivity of the covert investigation, which provides for the possibility of its conduct by investigators, operational officers (who, while carrying out the instructions of the investigator, have the authority of the investigator) and detectives;

- transformation of investigative actions and operative and search measures into investigative (search) actions and covert investigative (search) actions, respectively;

- covert investigative (search) actions as a component of covert investigation, the feature of which is covertness, is a kind of investigative (search) actions;

- logical construction of the mechanism of covert investigation depending on the gravity of the criminal offense (conducting covert investigation in criminal proceedings on serious or especially serious criminal offenses) and the need to intervene in private communication;

- special procedure for recording the progress and results of covert investigations, which establishes both general rules for recording investigative actions (Articles $103-107$ of the Criminal Procedural Code of Ukraine) (Law No. 4651-VI, 2010) and special rules for recording covert investigative (search) actions (Article 252, Article 265 of the Criminal Procedural Code of Ukraine) (Law No. 4651-VI, 2010). 
Oleh Tarasenko, Maksym Tsutskiridze, Artem Shevchishen, Yuri Yermakov y Dmytro Mirkovets
472 Establishment of the institution of covert investigation in the criminal justice system of Ukraine

The grounds for conducting covert investigation are:

- expediency and sufficiency of one or another covert investigative (search) action;

- compliance with the goal to be achieved;

- conducting only in cases, in which it is impossible to obtain the information on the offense and the perpetrator in another way (Part 2, Article 246 of the Criminal Procedural Code of Ukraine) (Law No. 4651-VI, 2010);

- peculiarities of conducting in terms of ensuring conspiracy, security of actors, etc.;

- compliance with the law in the course of covert investigation;

- legal support of each covert investigative (search) action, which is carried out during the covert investigation;

- observance of the rules of document circulation of the covert investigation (request of the investigator, decision of the prosecutor, decision of the investigating judge, instructions to the authorized operational units).

Thus, the institution of covert investigation in the criminal justice system of Ukraine is the system of legal norms that regulate a particular type of law enforcement (which is specific to the criminal process), determine the procedure for covert investigative (search) actions and the use of covert means for obtaining evidence by specially authorized actors with the court's permission.

\section{Bibliographic References}

CHERNIAVSKYI, Serhiy; TATAROV, Oleh; ALIEKSIEIEVA-PROTSIUK, Diana. 2013. The use of information of telecommunications operators and providers, their transport telecommunications networks, during the investigation of crimes: a guidance. National Academy of Internal Affairs, Ukraine.

COUNCIL OF EUROPE. 2011. Opinion on the Draft Criminal Procedure Code of Ukraine, DG-I (2011) 16: ENG - UKR. Available online. in: https://rm.coe.int/CoERMPublicCommonSearchServices/Display DCTMContent?documentId=09000016802e707c. Date of consultation: 14/09/2020.

DENYSENKO, Mykola. 2017. "Historical development of the system of normative regulation of covert investigative (search) actions" In: 
Scientific Bulletin of Dnipropetrovsk State University of Internal Affairs. No.1, pp. 310-323.

HAHACH, Vitalii. 2017. "Prosecutorial supervision in the form of procedural guidance in conducting audio and video surveillance of the person" In: Bulletin of Kharkiv National University of Internal Affairs. Special Issue, No. 1, pp. 42-50.

HARFIELD, Clive. 2010. "The governance of covert investigation". In: Melbourne University Law Review. No. 34, pp. 773-804.

LOFTUS, Bethan. 2019. "Normalizing covert surveillance: the subterranean world of policing" In: The British Journal of Sociology. Vol. 70, No. 5, pp. 2070- 2091. Available online. In: doi: https://doi.org/70.10.1111/14684446.12651. Date of consultation: 12/03/2020.

LOFTUS, Bethan; GOOLD, Benjamin. 2012. "Covert surveillance and the invisibilities of policing". In: Criminology \& Criminal Justice. Vol. 03, No. 12, pp. 275-288. Available online. In: https://doi. org/10.1177/1748895811432014. Date of consultation: 12/03/2020.

MIKHIEIENKO, Mikhail. 1984. Theoretical problems of evidence in the Soviet criminal process. PhD Dissertation. Kiev Order of Lenin and Order of the October Revolution State University named after T.H. Shevchenko.

NECHAI, Viktor. 2018. "Using the experience of other countries in conducting covert investigative (search) actions in the investigation of tax crimes committed by organized groups" In: Law and Society. No. 4, Part 2, pp. 250-256.

OMELIANENKO, Andrey. 2015. "Judicial control over the conduct of covert investigative (search) actions” In: Legea si viata. No.1, pp. 97-101.

POHORETSKYI, Mykola. 2012. "Introduction of the institute of covert investigative actions in law enforcement practice" In: Fight against organized crime and corruption (theory and practice). No. 2, pp. 56-63.

SALO, Oleh. 2018. Realization of powers by the head of body of pre-judicial investigation in conducting covert investigative (search) actions. $\mathrm{PhD}$ Dissertation. University of the State Fiscal Service of Ukraine.

SERHIEIEVA, Diana. 2014. Using the results of covert investigative (search) actions in criminal procedure evidence: a monograph.DP "Development". Kyiv, Ukraine.

SHABDE, Neela; CRAFT, Alan. 1999. "Covert video surveillance: an important investigative tool or a breach of trust?" In: Archives of Disease in Childhood. No. 81, pp. 291-294. 
Oleh Tarasenko, Maksym Tsutskiridze, Artem Shevchishen, Yuri Yermakov y Dmytro Mirkovets
474 Establishment of the institution of covert investigation in the criminal justice system of Ukraine

SHCHERBAKOVSKYI, Mikhailo; STEPANIUK, Ruslan; KIKINCHUK, Vasyl; ODERIY, Oleksiy; SVYRYDOVA, Liudmyla. 2020. "Evidentiary problems in the investigation of corruption crimes in Ukraine" In: Amazonia Investiga. Vol 9, No. 32, pp. 117-124. Available online. In: https://doi. org/10.34069/AI/2020.32.08.12. Date of consultation: 12/03/2020.

SPILNYK, Serhii. and KOMARNYTSKA, Oksana. 2015. "Investigator as an actor of covert investigative (search) actions: advantages and disadvantages" In: Court appeal. No. 1, pp. 15-25.

TAHIIEV, Sadig. 2015. The institution of covert investigative (search) actions in the criminal process of Ukraine: a monograph. Desna Polygraph. Chernihiv, Ukraine.

TATAROV, Oleg. 2016. "Some problems in conducting covert investigative (search) actions” In: Bulletin of criminal proceedings. No. 3/2016, pp. 69-77.

UKRAINE. 2010. Law 4651-VI, of April 18, Criminal Procedure Code of Ukraine. Official Gazette of the Verkhovna Rada of Ukraine of April 2010, no. 9-10, no. 11-12, no. 13 , p.88.

UKRAINE. 1960. Law 1001-05, of December 28, Criminal Procedure Code of Ukraine. Official Gazette of the Verkhovna Rada of Ukrainian SSR of December 1960, no. 2, p. 15.

UKRAINE. 2001. Law 2670-III of July 12, on the Amendments to the Criminal Procedure Code of Ukraine. Official Gazette of the Verkhovna Rada of Ukraine of July 2001, no. 44, p. 234.

VERKHOVNA RADA OF UKRAINE. 2012. Order No. $114 / 1042 / 516 / 1199 / 936 / 1687 / 5$. On the statement of the Instruction on the organization of the carrying out of covert investigation actions (raid) and use of its results in criminal proceedings. Official Gazette of the Verkhovna Rada of Ukraine, Kyiv, Ukraine, November 16, 2012. Available online. In: https://zakon.rada.gov.ua/laws/show/vo11490o12\#Text. Date of consultation: 12/03/2020. 
Vol. 39 N $^{\circ} 69$

Esta revista fue editada en formato digital y publicada en julio de 2021, por el Fondo Editorial Serbiluz, Universidad del Zulia. Maracaibo-Venezuela 